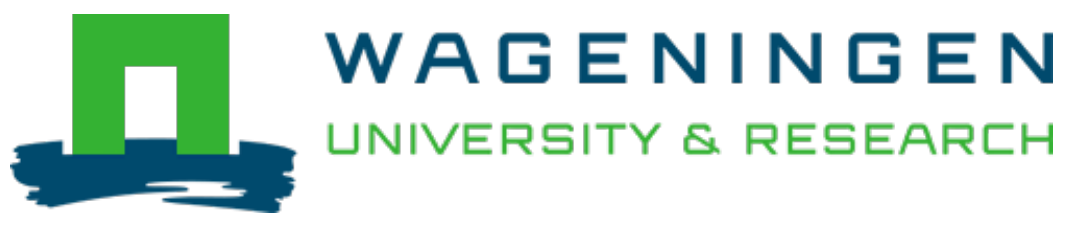

\title{
Environmental risk assessment of pesticides currently applied in Ghana
}

\section{Chemosphere}

Onwona-Kwakye, Michael; Hogarh, Jonathan N.; Brink, Paul J.

https://doi.org/10.1016/j.chemosphere.2020.126845

This article is made publicly available in the institutional repository of Wageningen University and Research, under the terms of article $25 \mathrm{fa}$ of the Dutch Copyright Act, also known as the Amendment Taverne. This has been done with explicit consent by the author.

Article $25 \mathrm{fa}$ states that the author of a short scientific work funded either wholly or partially by Dutch public funds is entitled to make that work publicly available for no consideration following a reasonable period of time after the work was first published, provided that clear reference is made to the source of the first publication of the work.

This publication is distributed under The Association of Universities in the Netherlands (VSNU) 'Article $25 \mathrm{fa}$ implementation' project. In this project research outputs of researchers employed by Dutch Universities that comply with the legal requirements of Article $25 \mathrm{fa}$ of the Dutch Copyright Act are distributed online and free of cost or other barriers in institutional repositories. Research outputs are distributed six months after their first online publication in the original published version and with proper attribution to the source of the original publication.

You are permitted to download and use the publication for personal purposes. All rights remain with the author(s) and / or copyright owner(s) of this work. Any use of the publication or parts of it other than authorised under article $25 \mathrm{fa}$ of the Dutch Copyright act is prohibited. Wageningen University \& Research and the author(s) of this publication shall not be held responsible or liable for any damages resulting from your (re)use of this publication.

For questions regarding the public availability of this article please contact openscience.library@wur.nl 


\title{
Environmental risk assessment of pesticides currently applied in Ghana
}

\author{
Michael Onwona-Kwakye ${ }^{\text {a, b }}$, Jonathan N. Hogarh ${ }^{c}$, Paul J. Van den Brink ${ }^{\text {a, d, * }}$ \\ a Aquatic Ecology and Water Quality Management Group, Wageningen University, P.O. Box 47, 6700, AA, the Netherlands \\ ${ }^{\mathrm{b}}$ Environmental Protection Agency, P. O. Box M326, Accra, Ghana \\ ${ }^{c}$ Department of Environmental Science, College of Science, Kwame Nkrumah University of Science and Technology, Kumasi, Ghana \\ ${ }^{\mathrm{d}}$ Wageningen Environmental Research, P.O. Box 47, 6700, AA, the Netherlands
}

\section{H I G H L I G H T S}

- A pesticide use survey was conducted in central, greater Accra and eastern Ghana.

- Environmental risks were calculated using a first tier model.

- Many pesticides pose serious risks to aquatic and terrestrial organisms.

- Second tier risk assessment using SSD refined the risks to aquatic organisms.

- Pesticide use was a factor of 1.3-13 times higher than recommended.

\section{A R T I C L E I N F O}

\section{Article history:}

Received 9 February 2020

Received in revised form

17 April 2020

Accepted 18 April 2020

Available online $\mathrm{xxx}$

Handling Editor: Willie Peijnenburg

\section{Keywords:}

Pesticide

Risk assessment

Environment

Models

Ghana

\begin{abstract}
A B S T R A C T
Registration of pesticides for use in Ghana is based on prospective environmental risk assessment (ERA) to assess the risks of future pesticide use on the environment. The present study evaluated whether pesticides currently used by Ghanaian farmers may harm the aquatic and terrestrial environment under day-to-day farm practice by performing a 1st tier ERA for terrestrial and aquatic environment and a 2nd tier ERA for the aquatic environment using existing scenarios and models. Results of the 1st tier risk assessment indicated that in the investigated regions in south Ghana, many pesticides might pose an acute risk to aquatic ecosystems adjacent to the treated fields while lambda cyhalothrin, chlorpyrifos, cypermethrin, dimethoate, mancozeb, carbendazim, sulphur, maneb and copper hydroxide may pose the highest chronic risks. Butachlor, dimethoate and carbendazim may pose acute risks to the terrestrial soil ecosystem, while glyphosate, chlorpyrifos, imidacloprid, dimethoate, mancozeb, carbendazim, maneb, copper hydroxide and cuprous oxide may pose the highest chronic risks. Many insecticides and some fungicides may pose acute risks to bees and terrestrial non-target arthropods. The 2nd tier acute aquatic risk assessment showed that most risks were substantiated using species sensitivity distribution (SSD). Actual pesticide use was a factor of 1.3-13 times higher than the recommended label instructions, indicating a general practice of overdosing. The case study shows that the PRIMET model in combination with the SSD concept may offer pesticide registration authorities in Ghana a means to assess environmental risks associated with pesticide usage in a user-friendly and cost-effective manner.
\end{abstract}

(๑) 2020 Elsevier Ltd. All rights reserved.

\section{Introduction}

Agriculture makes a big contribution to the economy of Ghana ranking second to the services sector in terms of gross domestic

\footnotetext{
* Corresponding author. Aquatic Ecology and Water Quality Management Group Wageningen University, P.O. Box 47, 6700, AA, the Netherlands.

E-mail address: paul.vandenbrink@wur.nl (P.J. Van den Brink).
}

product (GSS Ghana Statistical Service, 2015). Inputs such as pesticides, fertilizers and improved planting materials are increasingly used (WAAPP West Africa Agricultural Productivity Programme, 2014). The use of pesticides is important to protect crops from pests which has significantly reduced losses and improved the yield of crops such as cereals, vegetables and fruits (MOFA Ministry of Food and Agriculture, 2003). Information from the Environmental Protection Agency of Ghana indicated that 540 pesticides have been 
registered and are available for use in agriculture and public health as of December 2015 (Ghana EPA, 2015). Pesticides applied to the field are of concern because of the risk of pollution, especially to vulnerable aquatic and terrestrial ecosystems (Aktar et al., 2009). The need to monitor the environmental risks of pesticides has been highlighted (Vijver et al., 2017), but Ghana's pesticide law does not have the necessary regulation to adequately address this issue (NPASP (Northern Presbyterian Agricultural Services and Partners), 2012). Although pesticide use is high in Ghana, regulatory infrastructure is underdeveloped or not adequately enforced and capacity for routine monitoring programmes is lacking (NPASP (Northern Presbyterian Agricultural Services and Partners), 2012; Onwona Kwakye et al., 2019).

The registration of pesticides for use in Ghana is based on prospective risk assessment, while the development of the underpinning field of sciences, i.e. environmental chemistry and ecotoxicology, is in its early stages in Ghana. Local studies on pesticides regarding environmental risk assessment and particularly assessments of pesticides toxic effects on aquatic and terrestrial organisms have not been widely undertaken. A few studies that have been conducted involved pesticides exposure in rivers in the intensive cocoa growing areas of the Ashanti and Eastern Regions of Ghana. In Oda, Kowire and Atwetwe rivers, for example, mean pesticide concentrations found in water samples for lindane and endosulfan were 19.4 and $12.4 \mu \mathrm{g} / \mathrm{L}$ (Oda), 16.4 and $17.9 \mu \mathrm{g} / \mathrm{L}$ (Kowire), 20.5 and $21.4 \mu \mathrm{g} / \mathrm{L}$ (Atwetwe), respectively (Acquaah, 1997). A study published by Ntow in 2001 on organochlorine pesticide levels in water samples collected from streams near the city of Akumadan, a prominent vegetable-farming area in Ghana, showed that endosulfan sulfate was the most frequently occurring pesticide, detected in $78 \%$ of the sampled waters with a mean concentration of $30.8 \mu \mathrm{g} / \mathrm{L}$ (Ntow, 2001). In a similar study on the Volta Lake, lindane was detected in 38 samples, comprising of $76 \%$ of the analysed samples. Lindane and endosulfan were identified in relatively low mean concentrations of $\leq 0.008$ and $0.036 \mu \mathrm{g} / \mathrm{L}$, respectively (Ntow, 2005).

The current study evaluated whether current pesticide use by Ghanaian farmers may harm the environment under day-to-day farm practice by;

(i) performing a 1st tier environmental risk assessment to identify pesticides that may pose a risk to the aquatic and terrestrial environment using the PRIMET (Pesticides Risks in the Tropics to Man, Environment, and Trade) model (Peeters et al., 2008);

(ii) determining 2nd tier threshold levels that are protective of aquatic communities in the study site(s) using the Species Sensitivity Distribution (SSD) concept (Maltby et al., 2005);

(iii) evaluating the use of banned products and the overuse of pesticides, i.e. higher use than recommended dose.

The findings of this paper will contribute in filling the pesticide risk assessment gap with respect to available tools and procedures for especially the aquatic environment in Ghana. If risks are indicated, it is expected that the pesticide registration authority (Ghana Environmental Protection Agency; EPA) will use the information to initiate the necessary changes of farmers' pesticide use and that of other stakeholders to improve the quality of the aquatic and terrestrial environment.

\section{Materials and methods}

\subsection{Study sites}

A survey was conducted between May 2013 to January 2014 in four selected irrigation sites and a cocoa farming community involving 131 farmers. The sites were in the Central (Okyereko), Greater Accra (Weija and Ashaiman) and Eastern (Tontro/New Tafo and Akuse) regions of Ghana (Fig. 1). The study sites were chosen to reflect i) the steady increase of crop farming in the country, ii) the regions which uses pesticides intensively and iii) the regions being representative of Ghana in terms of agricultural advancement, crops grown, geography, and climate, among others (Dickson and Benneh, 1998; MOFA Ministry of Food and Agriculture, 2011). The system of farming was mainly mono-cropping for each of the sites.

Prior informed consent was obtained from each respondent and permission to carry out research at the sites was obtained from the scheme managers of the irrigation sites and from the owners of the cocoa farms. Information on pesticides used, application dose, and frequency were obtained from the farmers by way of questionnaire administration and records of observations of farmers whilst working in the field. The application rate of the pesticides being applied was particularly noted and compared to the recommended rates on the pesticide label (see Table SI 1; supplementary information for questionnaire used).

\subsection{The PRIMET model}

The 1st tier risk assessment of the pesticides to the aquatic and terrestrial environment was performed by applying the risk assessment model PRIMET (Pesticide Risks in the Tropics to Man, Environment and Trade; version 2.0) using hypothetical exposure scenarios (Peeters et al., 2008). To perform a risk assessment in PRIMET, a scenario describing the physical properties of the environmental compartment must be provided as well as data on the physico-chemical properties of the pesticides and the sensitivity of the organisms under evaluation. Scenarios of actual pesticide use were limited to application method, dosages (g active ingredient (a.i.)/ha), application interval (d) and frequency of use reported by the farmers. Pesticide formulations that had been made of more than one active ingredient were separated into the different active ingredient concentrations (Table SI 2). For each environmental compartment (aquatic, soil, bee and non-target arthropods), PRIMET calculates an exposure concentration (Predicted Environmental Concentration, PEC) and a threshold concentration for effects (Predicted No Effect Concentration, PNEC), from which the Exposure Toxicity Ratio (ETR) can be calculated by dividing the PEC by the PNEC. An ETR lower than 1 indicates that no serious risks are expected, an ETR between 1 and 100 indicates that risks may be present, while an ETR of higher than 100 indicates that risks are very likely to occur. The PRIMET DSS (Decision Support System) is freely available on www.primet.wur.nl and incorporated in a Graphical User Interface.

\subsection{Physico-chemical data}

In order to calculate the exposure concentration using the PRIMET model, data on each of the pesticides' intrinsic physicochemical properties were mostly already available in the model and, if not, taken from literature sources. Most available data were collected for the temperate regions of Europe and North America, but were temperature corrected within the PRIMET model. Table SI 3 shows the pesticide physico-chemical characteristics required for the PRIMET model. The pesticide products and active ingredients evaluated are the most used pesticides in the study area. The variables in Table SI 3 were obtained from either the PPDB: Pesticide Properties DataBase (PPDB Pesticide Properties Database, 2020) or already given in the PRIMET database. 


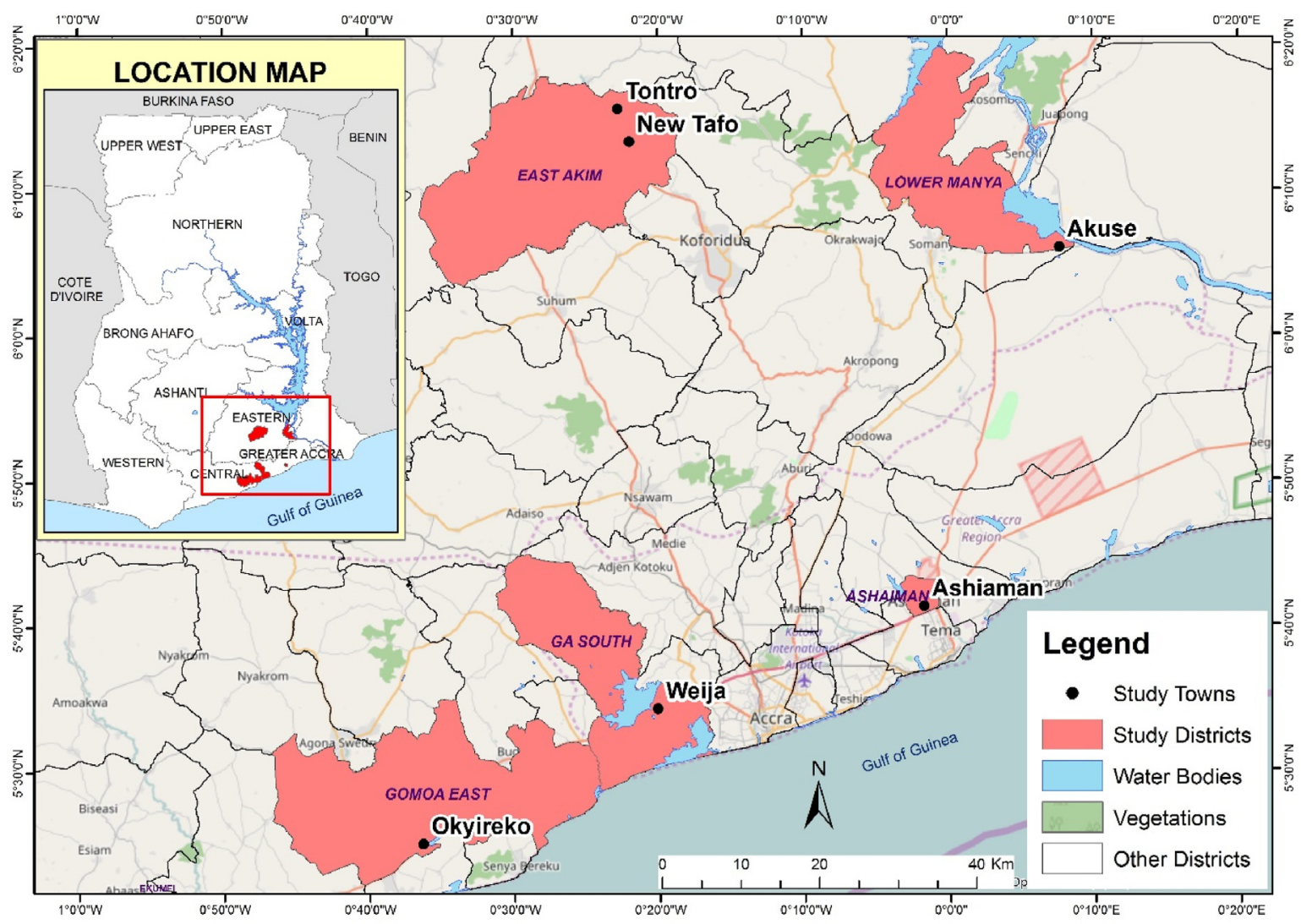

Fig. 1. Geographical location of the study sites in Ghana.

\subsection{First tier acute and chronic aquatic risk assessment}

In this 1 st tier risk assessment for the aquatic risk assessment only entry via spray drift was taken into consideration. An irrigation channel with an aquatic waterway of $1 \mathrm{~m}$ wide at the bottom, a slope of 0.5 and a water depth of $0.5 \mathrm{~m}$ was used for the aquatic scenario. The length from which the channel received spray drift following the applications was $100 \mathrm{~m}$ with a flow velocity of $100 \mathrm{~m} /$ day. The water phase was assumed to contain $1 \mathrm{~g} / \mathrm{L}$ of suspended solids with an organic matter content of $50 \%$, while the water temperature was taken to be $30^{\circ} \mathrm{C}$. The climate of Akuse, Okyereko, Ashaiman and Weija is of the tropical savannah type and characterized by a bimodal rainfall pattern. Average annual rainfall ranges from 625 to $1000 \mathrm{~mm}$. Mean annual temperature is $29^{\circ} \mathrm{C}$ and decreases to $26^{\circ} \mathrm{C}$ in July and August (http://mofa.gov.gh/site/?page_ id=2985; GSS Ghana Statistical Service, 2014). New Tafo/Tontro lies in the moist semi-deciduous forest which is also characterized by two main rainfall seasons. The mean annual rainfall is between 125 and $175 \mathrm{~mm}$. Temperatures are found to be fairly uniform ranging between $26^{\circ} \mathrm{C}$ in August and $30^{\circ} \mathrm{C}$ in March and characteristic of a typical tropical climate (GSS Ghana Statistical Service, 2014; Abban et al., 2018). Degradation and volatilisation rates of the pesticides from the watercourse are temperature dependent and their values were adjusted to the water temperature of $30^{\circ} \mathrm{C}$ used in this study as described by Peeters et al. (2008).

Pesticides were applied using hand-pressured backpack knapsack (Matabi 15L). The spraying was done with the lance positioned in front of the applicators while they walked through the crops, also directly next to water courses. It was assumed that on the average $10 \%$ of the amount of pesticide applied per ha on the crops would reach the water surface by spray drift based on empirical drift data from knapsack sprayers showed by Snelder et al. (2008).

The data was entered into the PRIMET model to calculate acute and chronic PECs. To calculate the 1st tier acute Exposure Toxicity Ratio (ETR), this PEC was then divided by acute or chronic PNEC. The acute and chronic PNECs are based on toxicity data in the form of EC50 and NOEC data for selected standard test species from different trophic levels, namely algae (primary producers), Daphnia (invertebrates) and fish (vertebrates). The toxicity data extracted from these databases were for the acute static tests for freshwater invertebrates $(48 \mathrm{~h})$, vertebrates $(96 \mathrm{~h})$ and primary producers ( $72 \mathrm{~h}$ and $96 \mathrm{~h}$ ) and for the chronic the extracted toxicity data were Daphnia (21 days) and fish (28 days). The relevant EC50 and NOEC data were extracted from the USEPA ECOTOX (USEPA, 2020a), the RIVM database (De Zwart, 2002) and the Pesticide Manual (Tomlin, 2000). The toxicity values used to calculate the 1st tier PNECs are provided in Table SI 2.

These acute PNECs also incorporated an assessment factor (100 for fish and Daphnia and 10 for algae) and the lowest resulting PNEC was used as the threshold concentration of effects (Table SI 2). These assessment factors were used to extrapolate from the EC50 level to a concentration at which no effects on the organisms were expected and to account for interspecies variation, and were taken from the uniform principles of the EU pesticide directive (EU European Union, 1997; Van den Brink et al., 2005). To calculate the chronic Exposure Toxicity Ratios $\left(\mathrm{ETR}^{\mathrm{n}}\right)$, a time weighted average PECs for fish (default period of 28 days) and daphnia (default period of 21 days) were calculated. These PECs were divided by their respective chronic PNECs for Daphnia (invertebrates) and fish (vertebrates), using an assessment factor of 10 . When the resulting chronic PNEC was higher than the acute one, the acute PNEC was used for the chronic risk assessment. The 
assessment factors used in the PRIMET model are regarded as conservative for most of the chemicals evaluated in this study (Brock and Van Wijngaarden, 2012; Brock et al., 2016; Van Wijngaarden et al., 2015; Rico et al., 2019; Van Wijngaarden and Arts, 2018).

\subsection{First tier acute and chronic terrestrial risk assessment}

For the terrestrial risk assessments the toxicity values already incorporated in the PRIMET model were used. The terrestrial soil (earthworms) scenario included an acute 14 day LC50 and a chronic NOEC for reproduction as effect endpoints using a default extrapolation factor of 0.1 and 0.2 for acute and chronic effect assessment of earthworm, respectively to calculate the PNEC (EU European Union, 1997). The exposure scenario included a bulk density of $1.0 \mathrm{~g} / \mathrm{cm}^{3}$ (Sally and Abernethy, 2002) of the soil, a depth of $0.05 \mathrm{~m}$ and the individual pesticide dose applied ( $\mathrm{g}$ a. $\mathrm{i} / \mathrm{ha}$ ), number of applications and application interval as obtained from the field survey.

The scenario for the bees included the acute LD50 (24 h and $48 \mathrm{~h}$ ) and the individual dose ( $\mathrm{g}$ a. i./ha) of the pesticides applied. Likewise, for the non-target arthropod (NTA), an acute median lethal rates (LR50, in $\mathrm{g} / \mathrm{ha}$ ), a vegetation scenario with a default distribution factor of 10, an extrapolation factor for effect assessment of NTA with a default value of 2 and a default drift factor value of 0.0277 as well as the number of pesticide applications ( $\mathrm{g} \mathrm{a} . \mathrm{i} / \mathrm{ha}$ ) were used (Peeters et al., 2008). The climatic conditions for the $1 \mathrm{st}$ tier terrestrial risk assessment were the same as that described under the aquatic risk assessment.

Subsequently, the calculated acute and chronic soil PEC was then divided by the 1 st tier acute and chronic PNEC to calculate the acute and chronic ETR respectively. For NTAs and bees only an acute risk assessment was performed due to a lack of toxicity data. For NTAs an in-field and off-field ETR was calculated with the latter being a factor of 100 lower (Peeters et al., 2008).

\subsection{Second tier acute pesticide threshold levels for aquatic communities}

To refine the threshold values protective for ecological risk of insecticides, fungicides and herbicides to freshwater ecosystems in the study area, the species sensitivity distribution (SSD) concept was used to calculate the 2nd tier acute PNEC for the chemicals indicated to pose an acute risk to aquatic ecosystems in the 1st tier. This PNEC was compared to the 1 st tier acute PEC as calculated by PRIMET in order to calculate the 2nd tier ETR. Due to data constraints it was not possible to perform a 2nd tier acute risk assessment for the other environmental compartments as well as to perform 2nd tier chronic risk assessments.

When available, the SSD derived HC5 (Hazardous Concentrations 5\%) values present in Van den Brink et al. (2006) and Maltby et al. $(2005,2009)$ were used as 2nd tier acute PNECs (Table 3). In order to construct the SSDs for the remaining compounds, acute aquatic single-species were collated from the EPA ECOTOX database (USEPA, 2020a). Data selection criteria followed those of Maltby et al. $(2005,2009)$ and Van den Brink et al. (2006), where the selected endpoints were median lethal concentration (LC50) or median effect concentration (EC50) regarding immobility for animals and EC50 regarding biomass or growth for plants. The test durations selected were $2-21 \mathrm{~d}$ for vertebrates, $1-7 \mathrm{~d}$ for invertebrates, $2-28 \mathrm{~d}$ for macrophytes, and $1-7 \mathrm{~d}$ for algae. Genera data were only used if no species data were reported for a genus. Each species was represented only once per compound in the analysis. The following data manipulations were performed where there were multiple toxicity values for a taxon:
- The lowest value was selected where several duration times, temperatures, life stages, water types, etc., were studied in the same experiment.

- The geometric mean was taken for data for the same species (and endpoint), but from different experiments.

The SSD generator developed by US EPA (USEPA, 2020b) was used to generate SSDs and median HC5 values (Hazardous Concentration 5\%) and their 95\% confidence interval. A log-normal distribution model by Aldenberg and Jaworska (2000) was fitted to a minimum of six data points, with model fit being evaluated using the Anderson- Darling goodness-of-fit test.

All arthropod data (crustaceans and insects) was included to construct SSD for insecticides, all aquatic data (vertebrates; invertebrates; and primary producers) for fungicides and all data for primary producers (algae and macrophytes) for herbicides (Maltby et al., 2005, 2009; Van den Brink et al., 2006). The analysis was applied to the pesticide crop combination for which only a potential or likely acute risk was indicated in the 1 st tier calculation (i.e. ETR $>1$ ). The analysis however focused on 19 pesticide compounds being 7 herbicides, 5 insecticides and 7 fungicides (Table 3 ).

\subsection{Overuse of pesticides}

The third aim was to evaluate whether the farmers overdose pesticides during normal day-to-day use and if products being used had been banned for use or not. The status of pesticides identified to be in use was cross-checked as well as application rate compared to the recommended rate provided by the registration authorities (Ghana EPA, 2015) and as indicated on the label instructions.

\section{Results}

\subsection{First tier risk assessment}

The data set included 33\% insecticides, 30\% fungicides and 37\% herbicides as obtained from the individual active ingredient application dosages (Table SI 2). The application rate per hectare, application interval, number of applications per season, and crops applied to at the study sites are given in Table SI 2. For the risk assessment, the 1st tier ETRs, the ranges of the ETRs and percentage of ETRs $>1$ were calculated (Tables 1 and 2) using use patterns for 32 different active ingredients and their physico-chemical properties (Table SI 3). Together with their tier-1 acute $\mathrm{L}(\mathrm{E} / \mathrm{D} / \mathrm{R}) \mathrm{C}_{50}$ (Table SI 4) and tier-1 chronic NOEC (Table SI 5) data. All this data was included in the model to classify each application dosage in three categories of risk: 'no risk' (ETR < 1), 'possible risk' $(1<$ ETR < 100) and 'definite risk' (ETR > 100) for each environmental compartment. Some active ingredients showed ranges in ETRs spanning multiple categories due to differences with regards to the dosage of active ingredient applied per hectare (Tables 1 and 2).

Only for the insecticide emmamectin benzoate no acute and chronic aquatic risk assessment could be performed due to a lack of data, while this was not possible for pyribenzoxim and emmamectin benzoate for the acute soil risk assessment. Only for $53 \%$ of the compounds a chronic soil risk assessment could be performed while for all compounds an acute risk assessment for bees could be performed. For $37 \%$ of the compounds an acute risk assessment could be performed for NTAs (Tables 1 and 2).

\section{2. 'No risk'}

For the following pesticides 'no acute risk' were indicated based on the calculated highest acute ETRs for the aquatic environment: 
Table 1

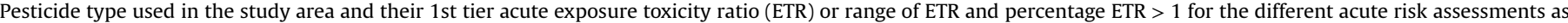

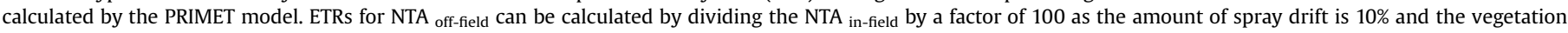
distribution factor is 10 (Peeters et al., 2008).

\begin{tabular}{|c|c|c|c|c|c|c|c|c|c|c|}
\hline \multirow{2}{*}{$\begin{array}{l}\text { Pesticide Active } \\
\text { Ingredient }\end{array}$} & \multirow[t]{2}{*}{ Class } & \multirow{2}{*}{$\begin{array}{l}\text { Number of } \\
\text { case(s) }\end{array}$} & \multicolumn{2}{|l|}{ Aquatic } & \multicolumn{2}{|l|}{ Terrestrial (soil) } & \multicolumn{2}{|c|}{ Terrestrial (bees) } & \multicolumn{2}{|c|}{ Terrestrial (NTA in-field $)$} \\
\hline & & & $\begin{array}{l}\text { ETR/Range of } \\
\operatorname{ETR}(s)\end{array}$ & $\begin{array}{l}\% \text { of } \\
\text { ETR }>1\end{array}$ & $\begin{array}{l}\text { ETR/Range of } \\
\operatorname{ETR}(s)\end{array}$ & $\begin{array}{l}\% \text { of } \\
\text { ETR }>1\end{array}$ & $\begin{array}{l}\text { ETR/Range of } \\
\operatorname{ETR}(s)\end{array}$ & $\begin{array}{l}\% \text { of } \\
\text { ETR }>1\end{array}$ & $\begin{array}{l}\text { ETR/Range of } \\
\operatorname{ETR}(s)\end{array}$ & $\begin{array}{l}\% \text { of } \\
\text { ETR }>1\end{array}$ \\
\hline Glyphosate & Herbicide & 4 & $0.019-0.21$ & 0 & $0.012-0.13$ & 0 & $0.086-0.94$ & 0 & NA & NA \\
\hline Paraquat & Herbicide & 2 & $1.1-6.0$ & 100 & $0.0040-0.022$ & 0 & $0.66-3.7$ & 50 & NA & NA \\
\hline Butachlor & Herbicide & 1 & 15 & 100 & 86 & 100 & 0.67 & 0 & NA & NA \\
\hline Pendimethalin & Herbicide & 2 & $7.9-26$ & 100 & $0.016-0.052$ & 0 & $0.24-0.78$ & 0 & NA & NA \\
\hline Propanil & Herbicide & 2 & $1.5-2.8$ & 100 & $0.013-0.024$ & 0 & $0.15-0.28$ & 0 & $4138^{\mathrm{a}}-7655^{\mathrm{a}}$ & 100 \\
\hline Bensulfuron methyl & Herbicide & 1 & 1.5 & 100 & 0.0017 & 0 & 0.049 & 0 & 0.11 & 0 \\
\hline Bispyribac sodium & Herbicide & 1 & 0.0030 & 0 & $5.6 \mathrm{E}-04$ & 0 & 0.0056 & 0 & NA & NA \\
\hline $2,4-\mathrm{D}$ & Herbicide & 2 & $0.015-0.027$ & 0 & $0.015-0.028$ & 0 & $0.085-0.16$ & 0 & NA & NA \\
\hline Pretilachlor & Herbicide & 1 & 1.6 & 100 & 0.42 & 0 & 0.13 & 0 & NA & NA \\
\hline Pyribenzoxim & Herbicide & 1 & 0.00096 & 0 & NA & NA & 0.0080 & 0 & NA & NA \\
\hline Oxyfluorfen & Herbicide & 2 & $4.3-5.8$ & 100 & $0.0060-0.0080$ & 0 & $0.090-0.12$ & 0 & $0.16-0.21$ & 0 \\
\hline Lambda cyhalothrin & Insecticide & 3 & $274^{a}-4229^{a}$ & 100 & $6.4 \mathrm{E}-04-0.0099$ & 0 & $13-195^{a}$ & 100 & $192^{\mathrm{a}}-2960^{\mathrm{a}}$ & 100 \\
\hline Chlorpyrifos & Insecticide & 2 & $3425^{\mathrm{a}}-5479^{\mathrm{a}}$ & 100 & $0.050-0.079$ & 0 & $163^{\mathrm{a}}-260^{\mathrm{a}}$ & 100 & $3600^{a}-5760^{a}$ & 100 \\
\hline $\begin{array}{c}\text { Emmamectin } \\
\text { benzoate }\end{array}$ & Insecticide & 2 & NA & NA & NA & NA & $673^{a}-2009^{a}$ & 100 & NA & NA \\
\hline Imidacloprid & Insecticide & 1 & 0.00085 & 0 & 0.037 & 0 & $162^{\mathrm{a}}$ & 100 & $1841^{\mathrm{a}}$ & 100 \\
\hline Acetamiprid & Insecticide & 4 & $\begin{array}{l}1.40 \mathrm{E}-03- \\
0.0034\end{array}$ & 0 & $0.040-0.11$ & 0 & $0.0022-0.18$ & 0 & NA & NA \\
\hline Novaluron & Insecticide & 2 & 0.17 & 0 & $2.1 \mathrm{E}-04$ & 0 & 0.0032 & 0 & NA & NA \\
\hline Thiamethoxam & Insecticide & 2 & $\begin{array}{l}7.1 \mathrm{E}-04-8.5 \mathrm{E}- \\
04\end{array}$ & 0 & $\begin{array}{l}4.0 \mathrm{E}-04-4.8 \mathrm{E}- \\
04\end{array}$ & 0 & $120^{a}-144^{a}$ & 100 & NA & NA \\
\hline Bifenthrin & Insecticide & 4 & $0.52-4.2$ & 50 & $0.0028-0.023$ & 0 & $0.33-2.7$ & 50 & NA & NA \\
\hline Cypermethrin & Insecticide & 2 & $16-61$ & 100 & $0.012-0.047$ & 0 & $90-353^{a}$ & 100 & NA & NA \\
\hline Dimethoate & Insecticide & 2 & $1.2-4.7$ & 100 & $0.43-1.7$ & 50 & $167^{a}-653^{a}$ & 100 & NA & NA \\
\hline Carbofuran & Fungicide & 1 & 4.6 & 100 & 0.0011 & 0 & 10 & 100 & 3.4 & 100 \\
\hline Mancozeb & Fungicide & 3 & $16-202^{\mathrm{a}}$ & 100 & $0.029-0.35$ & 0 & $0.091-1.1$ & 33 & NA & NA \\
\hline Carbendazim & Fungicide & 2 & $6.4-13$ & 100 & $0.99-2.0$ & 50 & $0.16-0.32$ & 0 & $0.15-0.31$ & 0 \\
\hline Sulphur & Fungicide & 2 & $16-19$ & 100 & $0.0043-0.0052$ & 0 & $0.13-0.16$ & 0 & $1.5-1.8$ & 100 \\
\hline Maneb & Fungicide & 1 & $5719^{a}$ & 100 & 0.13 & 0 & 1.8 & 100 & NA & NA \\
\hline Copper hydroxide & Fungicide & 4 & $8.3-36$ & 100 & $0.0052-0.023$ & 0 & $0.12-0.52$ & 0 & $7088^{a}-26,570^{a}$ & 100 \\
\hline Metalaxyl & Fungicide & 2 & $0.0069-0.0096$ & 0 & $0.0011-0.0015$ & 0 & $0.0080-0.011$ & 0 & NA & NA \\
\hline Metalaxyl-M & Fungicide & 2 & $3.6 \mathrm{E}-04-0.0071$ & 0 & $2.4 \mathrm{E}-04-0.0048$ & 0 & $0.0024-0.047$ & 0 & NA & NA \\
\hline Cuprous oxide & Fungicide & 2 & $1.7-8.6$ & 100 & $0.0023-0.011$ & 0 & $0.026-0.13$ & 0 & $5.2-26$ & 100 \\
\hline
\end{tabular}

ETR values below 1 indicate no risk, between 1 and 100 a potential risk and above 100 a definite risk.

NA indicates that the ETR was not determined because toxicity data were not available.

a Represents a definite risk.

the herbicides glyphosate, bispyribac-sodium, 2, 4-D and pyribenzoxim, the insecticides imidacloprid, acetamiprid, novaluron and thiamethoxam and the fungicides metalaxyl and metalaxyl-M (Table 1). There were also no chronic ETRs greater than 1 indicating no chronic risk to the aquatic environment with respect to the same pesticides as well as many others (Table 2).

With the exception of butachlor, dimethoate and carbendazim all active ingredients showed no acute risk for terrestrial (soil) organisms while the chronic terrestrial (soil) ETRs ranged from 0.0047 to 0.78 for pendimethalin, oxyfluorfen, acetamiprid, novaluron, thiamethoxam, bifenthrin and carbofuran (Table 2).

No acute risk to bees were calculated for herbicides, with the exception of paraquat, for insecticides with the exception of lambda cyhalothrin, chlorpyrifos, emmamectin benzoate, imidacloprid, thiamethoxam, bifenthrin, cypermethrin, dimethoate, and for fungicides with the exception of carbofuran, mancozeb, and maneb. The other active ingredients showed no acute risk to bees with $\mathrm{ETR}_{\text {Terrestrial acute Bees }}=0.0022-0.94$ (Table 1 ).

No acute ETRs $>1$ to terrestrial non-target arthropods (NTA) were calculated for the herbicide bensulfuron methyl and oxyfluorfen and the fungicide carbendazim while for all other pesticides for which data were available a (possible) risk was calculated. The chronic ETRs could only be calculated for $37 \%$ of the compounds. The ETRs of the herbicide bensulfuron methyl and oxyfluorfen, the insecticide carbofuran and the fungicides carbendazim, sulphur and cuprous oxide were lower than 1
(Tables 1 and 2). It is clear that the chronic risk assessment for these organisms suffer from a lack of data as chronic, and even acute, toxicity data were not available for most compounds (Tables 1 and 2).

\section{3. 'Possible risk'}

The predicted PRIMET highest acute ETR values were between 1 and 100 for most of the herbicides (i.e. paraquat, butachlor, pendimethalin, propanil, bensulfuron methyl, pretilachlor and oxyfluorfen), some insecticides (bifenthrin, cypermethrin and dimethoate) and almost half of the fungicides (carbofuran, carbendazim, sulphur, copper hydroxide and cuprous oxide). All highest chronic ETR values predicted by PRIMET for cypermethrin, dimethoate, mancozeb, carbendazim, sulphur and copper hydroxide were between 1 and 100, indicating possible risks with respect to the aquatic environment (Tables 1 and 2).

The highest acute ETR predicted by PRIMET for the terrestrial soil environment were only larger than 1 for the herbicide butachlor, the insecticide dimethoate and fungicide carbendazim. They were also smaller than 100 and this indicating possible effects (Table 1). Chronic highest ETR between 1 and 100 were calculated for the herbicide glyphosate, the insecticides chlorpyrifos, imidacloprid and dimethoate and the fungicides mancozeb, carbendazim, maneb, copper hydroxide and cuprous oxide (Tables 1 and 2).

Acute highest ETRs between 1 and 100 for bees were calculated 
Table 2

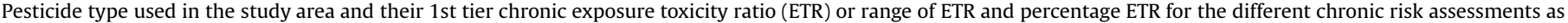
calculated by the PRIMET model.

\begin{tabular}{|c|c|c|c|c|c|c|}
\hline \multirow[t]{2}{*}{ Pesticide Active Ingredient } & \multirow[t]{2}{*}{ Class } & \multirow[t]{2}{*}{ Number of case(s) } & \multicolumn{2}{|l|}{ Aquatic } & \multicolumn{2}{|l|}{ Terrestrial (soil) } \\
\hline & & & ETR/Range of ETR(s) & $\%$ of ETR $>1$ & ETR/Range of ETR(s) & $\%$ of ETR $>1$ \\
\hline Glyphosate & Herbicide & 4 & 8.6E-04 - 0.0093 & 0 & $0.10-1.1$ & 25 \\
\hline Paraquat & Herbicide & 2 & $9.8 \mathrm{E}-05-5.4 \mathrm{E}-04$ & 0 & NA & NA \\
\hline Butachlor & Herbicide & 1 & 0.54 & 0 & NA & NA \\
\hline Pendimethalin & Herbicide & 2 & $0.16-0.54$ & 0 & $0.24-0.78$ & 0 \\
\hline Propanil & Herbicide & 2 & $0.069-0.13$ & 0 & NA & NA \\
\hline Bensulfuron methyl & Herbicide & 1 & 7.0E-04 & 0 & NA & NA \\
\hline Bispyribac sodium & Herbicide & 1 & $4.6-05$ & 0 & NA & NA \\
\hline $2,4-\mathrm{D}$ & Herbicide & 2 & $5.0 \mathrm{E}-04-9.3 \mathrm{E}-4$ & 0 & NA & NA \\
\hline Pretilachlor & Herbicide & 1 & 0.057 & 0 & NA & NA \\
\hline Pyribenzoxim & Herbicide & 1 & 4.3E-05 & 0 & NA & NA \\
\hline Oxyfluorfen & Herbicide & 2 & $0.38-0.51$ & 0 & $0.12-0.17$ & 0 \\
\hline Lambda cyhalothrin & Insecticide & 3 & $167-2577$ & 100 & NA & NA \\
\hline Chlorpyrifos & Insecticide & 2 & $401-642$ & 50 & $1.0-1.6$ & 100 \\
\hline Emmamectin benzoate & Insecticide & 2 & NA & 0 & NA & NA \\
\hline Imidacloprid & Insecticide & 1 & $1.9 \mathrm{E}-04$ & 0 & 4.0 & 100 \\
\hline Acetamiprid & Insecticide & 4 & $1.9 \mathrm{E}-06-4.2 \mathrm{E}-04$ & 0 & 0.00470 .43 & 0 \\
\hline Novaluron & Insecticide & 2 & 0.89 & 0 & 0.11 & 0 \\
\hline Thiamethoxam & Insecticide & 2 & 3.9E-05 - 4.7E-05 & 0 & $0.10-0.12$ & 0 \\
\hline Bifenthrin & Insecticide & 4 & $0.081-0.66$ & 0 & $0.022-0.18$ & 0 \\
\hline Cypermethrin & Insecticide & 2 & $1.8-7.1$ & 100 & NA & NA \\
\hline Dimethoate & Insecticide & 2 & $0.70-2.7$ & 50 & $2.5-9.7$ & 100 \\
\hline Carbofuran & Fungicide & 1 & 0.19 & 0 & 0.14 & 0 \\
\hline Mancozeb & Fungicide & 3 & $3.8-70$ & 100 & $0.21-2.6$ & 66 \\
\hline Carbendazim & Fungicide & 2 & $7.7-15$ & 100 & $6.7-13$ & 100 \\
\hline Sulphur & Fungicide & 2 & $1.4-1.7$ & 100 & NA & NA \\
\hline Maneb & Fungicide & 1 & $159^{\mathrm{a}}$ & 100 & 6.6 & 100 \\
\hline Copper hydroxide & Fungicide & 4 & $0.59-3.9$ & 50 & $0.47-1.5$ & 25 \\
\hline Metalaxyl & Fungicide & 2 & $4.5 \mathrm{E}-04-6.4 \mathrm{E}-04$ & 0 & NA & NA \\
\hline Metalaxyl-M & Fungicide & 2 & $1.4 \mathrm{E}-04-0.0072$ & 0 & NA & NA \\
\hline Cuprous oxide & Fungicide & 2 & $0.12-0.92$ & 0 & $0.25-1.3$ & 50 \\
\hline
\end{tabular}

ETR values below 1 indicate no risk, between 1 and 100 a potential risk and above 100 a definite risk.

NA indicates that the ETR was not determined because toxicity data were not available.

a Represents a definite risk.

Table 3

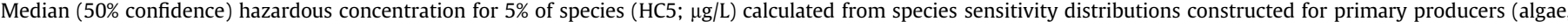

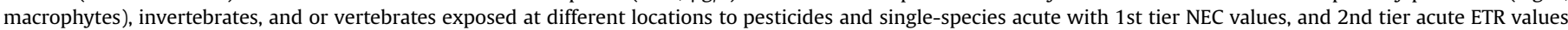
based on the 2nd tier PNEC values. For some pesticides multiple dosages were evaluated leading to an equal number of PEC and ETR values per pesticide.

\begin{tabular}{|c|c|c|c|c|c|c|c|}
\hline \multirow[t]{3}{*}{ Pesticide Product } & \multicolumn{4}{|l|}{ Tier-1 } & \multicolumn{2}{|l|}{ Tier-2 } & \multirow[t]{3}{*}{$\mathrm{ETR}=(\mathrm{PEC} / \mathrm{HC} 5)$} \\
\hline & \multicolumn{3}{|l|}{ PNEC $(\mu \mathrm{g} / \mathrm{L})$} & \multirow[t]{2}{*}{$\operatorname{PEC}(\mu \mathrm{g} / \mathrm{L})$} & \multirow[t]{2}{*}{ HC5 $(\mu \mathrm{g} / \mathrm{L})$} & \multirow[t]{2}{*}{ Reference } & \\
\hline & Primary Producers & Inverte-brates & Verte-brates & & & & \\
\hline \multicolumn{8}{|l|}{ Herbicide } \\
\hline Paraquat & 0.023 & 44 & 190 & $0.025 ; 0.14$ & 0.83 & This study & $0.030 ; 0.17$ \\
\hline Butachlor & 20 & 24 & 4.4 & 67 & NA & This study & NA \\
\hline Pendimethalin & 0.6 & 2.8 & 1.38 & $4.7 ; 15$ & 2.0 & Van den Brink et al. (2006) & $2.4 ; 7.5$ \\
\hline Propanil & 11 & 23.9 & 54 & $17 ; 31$ & 6.8 & This study & $2.5 ; 4.6$ \\
\hline Bensulfuron methyl & 2 & 1300 & 660 & 3.0 & NA & This study & $\mathrm{NA}$ \\
\hline Pretilachlor & 929 & 130 & 9 & 14 & NA & This study & NA \\
\hline Oxyfluorfen & 200 & 7.2 & 2.5 & $11 ; 14$ & 0.10 & This study & $110 ; 140$ \\
\hline \multicolumn{8}{|l|}{ Insecticide } \\
\hline Lambda cyhalothrin & 30 & 0.0036 & 0.0021 & $0.58 ; 0.60 ; 8.9$ & 0.003 & Maltby et al. (2005) & $193 ; 200 ; 2967$ \\
\hline Chlorpyrifos & 48 & 0.0010 & 0.013 & $3.4 ; 5.5$ & 0.07 & Maltby et al. (2005) & $49 ; 79$ \\
\hline Bifenthrin & 82 & 0.0011 & 0.0026 & $0.0047 ; 0.0047$ & 0.0051 & This study & $0.92 ; 0.92$ \\
\hline Cypermethrin & 10 & 0.0030 & 0.028 & $0.047 ; 0.18$ & 0.003 & Maltby et al. (2005) & $16 ; 60$ \\
\hline Dimethoate & 9040 & 20 & 302 & $24 ; 94$ & 1.6 & This study & $15 ; 59$ \\
\hline \multicolumn{8}{|l|}{ Fungicide } \\
\hline Carbofuran & 650 & 0.094 & 1.8 & 0.43 & 0.23 & Maltby et al. (2009) & 1.9 \\
\hline Mancozeb & 4.4 & 0.73 & 0.74 & $12 ; 88 ; 147$ & 89 & Maltby et al. (2009) & $0.13 ; 0.99 ; 1.7$ \\
\hline Carbendazim & 770 & 1.5 & 1.9 & $9.6 ; 19$ & 8 & Maltby et al. (2009) & $1.2 ; 2.4$ \\
\hline Sulphur & 6.3 & 0.63 & 0.63 & $9.8 ; 12$ & NA & This study & $\mathrm{NA}$ \\
\hline Maneb & 0.70 & 0.021 & 2 & 120 & 48 & Maltby et al. (2009) & 2.5 \\
\hline Copper hydroxide & 0.9 & 0.38 & 0.17 & $1.4 ; 2.3 ; 3.1 ; 6.2$ & 5.4 & This study & $0.26 ; 0.43 ; 0.57 ; 1.1$ \\
\hline Cuprous oxide & 14.7 & 4.5 & 2.07 & $3.6 ; 18$ & $22^{\mathrm{a}}$ & This study & 0.16 \\
\hline
\end{tabular}

NA indicates that the SSD was not determined because not enough toxicity data were available.

a Indicative, based on 7 species. 
for the herbicide paraquat, the insecticide bifenthrin, and the fungicides carbofuran, mancozeb and maneb (Table 1 ).

Possible acute risks (highest ETR values between 1 and 100) for in-field NTAs were calculated for the fungicides carbofuran, sulphur and cuprous oxide (Table 1 ).

\section{4. 'Definite risk'}

The PRIMET predicted definite acute risk (highest ETR values > 100) values for the aquatic environment for the insecticides lambda cyhalothrin and chlorpyrifos and the fungicides mancozeb and maneb, while chronic definite risks were calculated for the insecticides lambda cyhalothrin and chlorpyrifos and the fungicide maneb (Tables 1 and 2).

No definite acute or chronic risks (highest ETR values $>100$ ) were calculated for the soil compartment while definite acute risks values for bees included those for the insecticides lambda cyhalothrin, chlorpyrifos, emmamectin benzoate, imidacloprid, thiamethoxam, cypermethrin and dimethoate (Tables 1 and 2). For the non-target arthropods, PRIMET calculated highest acute ETR values $>100$ for the herbicide propanil, the insecticides lambda cyhalothrin, chlorpyrifos and imidacloprid and the fungicide; copper hydroxide (Table 1 ).

\subsection{Second tier aquatic risk assessment}

For 15 of the 19 pesticides an HC5 could be calculated, however in the case of cuprous oxide only based on 7 data points instead of the required 8 ones (Table 3). The median factor at which the PNEC went up between the 1 st and 2 nd tier was 4.6. The highest increase in PNEC was observed for maneb (from $0.021 \mu \mathrm{g} / \mathrm{L}$ to $48 \mu \mathrm{g} / \mathrm{L}$, while a decrease was observed for 3 compounds (propanil, oxyfluorfen and dimethoate).

Paraquat, bifenthrin and cuprous oxide moved from the possible risk category to the no risk category, while 7 pesticides stayed in the possible risk category (Table 3 ). Only oxyfluorfen moved up in its risk category, i.e. from possible risk to definite risk. Chlorpyrifos, mancozeb and maneb moved from the definite risk category to the possible risk category, while lambda cyhalothrin was the only chemical staying in the definite risk category (Table 3 ).

\subsection{Overdosing of pesticides}

Table 4 shows that a number of pesticides have been applied in excess by farmers at the study sites as compared to the recommended dosages on the approved pesticide labels by Ghana pesticide registration authorities. Based on the mean of the minimum and maximum applied and recommended dosages, the average overdose factor was 4.5 with the highest values for the insecticides lambda cyhalothrin (applied as Karate Conti-Halothrin, Pawa and/or Stricker) and cypermethrin and dimethoate applied as a mixture using the Cymethoate and/or Cydim Super formulations. The lowest overdose factor values were observed for the fungicides sulphur (applied as Sulfa 80 WP), the insecticide mixture lambda cyhalothrin and acetamiprid (applied as K-Optimal), the herbicide mixture pretilachlor and pyribenzoxim (Solito formulation) and the herbicide butachlor (applied as Ceres Butachlor). No formulation was underdosed (Table 4).

\section{Discussion}

This study reveals that environmental risks may be expected with regards to the use of pesticides in the case study areas of Ghana judging from the results of the environmental risk assessment in terms of ETRs for the aquatic (algae, daphnia and fish) and terrestrial (worms, bees and NTAs) compartments (Tables 1-3). This included the overdosing of pesticides applied by farmers, in comparison to the recommended dosages (Table 4). There was, however, no record of farmers using banned pesticide products in the study area.

\subsection{Aquatic risk assessment}

Aquatic ecosystems provide direct goods and services like clean drinking water, fish and aquatic macrophytes for consumption and indirect services like water purification, water retention and climate regulation (Grizzetti et al., 2016). It is, therefore, of most importance that aquatic ecosystems are of good ecological status and not impaired by chemicals such as pesticides. Among others, that was the reason for us to perform the aquatic risk assessment of the pesticide use dosages collected within this paper to evaluate the agricultural practices in the Central, Greater Accra and Eastern

Table 4

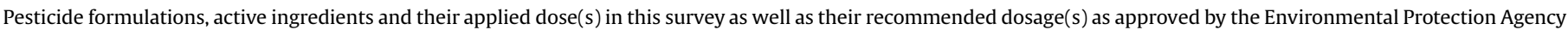

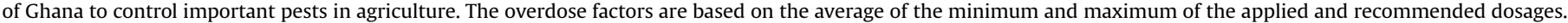

\begin{tabular}{|c|c|c|c|c|c|c|}
\hline Pesticide formulation & $\begin{array}{l}\text { Pesticide } \\
\text { Class }\end{array}$ & Active Ingredient(s) & $\begin{array}{l}\text { Applied dose, L/Ha, } \\
\mathrm{kg} / \mathrm{Ha}\end{array}$ & $\begin{array}{l}\text { Recommended dose on label, L/ } \\
\mathrm{Ha}, \mathrm{kg} / \mathrm{Ha}\end{array}$ & $\begin{array}{l}\text { Overdose } \\
\text { factor }\end{array}$ & Site(s) \\
\hline $\begin{array}{l}\text { Ceresate; Chemosate; Roundup; Power; } \\
\text { Sunphosate }\end{array}$ & Herbicide & Glyphosate & $1.2-9.8 \mathrm{~L}$ & $0.5-2.5 \mathrm{~L}$ & 3.7 & AS \\
\hline Gramoxone; M-Quat & Herbicide & Paraquat & $1.5-8.3 \mathrm{~L}$ & $1.5-3.0 \mathrm{~L}$ & 2.2 & AS \\
\hline Ceres Butachlor & Herbicide & Butachlor & $6.7 \mathrm{~L}$ & $4.0 \mathrm{~L}$ & 1.7 & $\mathrm{OK}$ \\
\hline Condax; Londax & Herbicide & Bensulfuron methyl & $0.42 \mathrm{Kg}$ & $0.0030-0.10 \mathrm{Kg}$ & 8.2 & AS, OK, AK \\
\hline Solito & Herbicide & Pretilachlor + Pyribenzoxim & $2.0 \mathrm{~L}$ & $1.0-1.5 \mathrm{~L}$ & 1.6 & AK \\
\hline Zoomer & Herbicide & Oxyfluorfen + Glyphosate & $1.5-2.0 \mathrm{~L}$ & $0.75-0.90 \mathrm{~L}$ & 2.1 & WJ \\
\hline Stomp 445 CS; Alligator & Herbicide & Pendimethalin & $3.0-9.8 \mathrm{~L}$ & $2.5-3.0 \mathrm{~L}$ & 2.3 & AS, AK \\
\hline Bounty & Herbicide & Bispyribac sodium & $0.10 \mathrm{~L}$ & $0.015-0.050 \mathrm{~L}$ & 3.1 & $\mathrm{AK}$ \\
\hline Karate; Conti-Halothrin; Pawa; Stricker & Insecticide & Lambda Cyhalothrin & $1.0-15 \mathrm{~L}$ & $0.60 \mathrm{~L}$ & 13 & $\begin{array}{l}\text { AS, OK, WJ, } \\
\text { AK }\end{array}$ \\
\hline Attack & Insecticide & Emamectin benzoate & $0.62-1.9 \mathrm{~L}$ & $0.25-0.30 \mathrm{~L}$ & 4.6 & AS, OK, WJ \\
\hline K-Optimal & Insecticide & $\begin{array}{l}\text { Lambda } \\
\text { cyhalothrin }+ \text { Acetamiprid }\end{array}$ & $1.5 \mathrm{~L}$ & $1.0 \mathrm{~L}$ & 1.5 & $\mathrm{OK}$ \\
\hline Cymethoate, Cydim Super & Insecticide & Cypermethrin + Dimethoate & $2.5-9.8 \mathrm{~L}$ & $0.50 \mathrm{~L}$ & 12 & AS, OK \\
\hline Benco & Fungicide & Mancozeb & $5.9-9.9 \mathrm{Kg}$ & $0.80-2.0 \mathrm{Kg}$ & 5.6 & AS, WJ, OK \\
\hline Carbendazim $50 \mathrm{WP}$ & Fungicide & Carbendazim & $0.80-1.6 \mathrm{Kg}$ & $0.13-0.26 \mathrm{Kg}$ & 6.2 & WJ \\
\hline Sulfa 80 WP & Fungicide & Sulphur & $0.80-0.99 \mathrm{Kg}$ & $0.67 \mathrm{Kg}$ & 1.3 & AS, AK \\
\hline Maneb 80 WP & Fungicide & Maneb & $9.0 \mathrm{Kg}$ & $2.0-4.0 \mathrm{Kg}$ & 3.0 & WJ, AS \\
\hline
\end{tabular}

$\mathrm{AS}=$ Ashaiman, $\mathrm{AK}=$ Akuse, $\mathrm{WJ}=$ Weija, $\mathrm{OK}=$ Okyereko. 
regions of Ghana.

Firstly, this study applied the PRIMET model for calculating environmental impact of pesticide use, and demonstrated that pesticide use poses serious potential acute and chronic risks to the aquatic environment, if aquatic ecosystems are present adjacent to the treated fields (Tables 1 and 2). Malherbe et al. (2013) reported ETR values of $0.01,0.2,0.2-0.5$ and 73 for dimethoate, glyphosate, carbendazim and paraquat respectively while Ansara-Ross et al. (2008) reported an ETR of 0.3 for pendimethalin for aquatic ecosystems in South Africa. In this study the calculated acute 1st tier ETR for pendimethalin ranged between 7.9 and 26 (Table 1), indicating possible acute risk, which is substantiated by the 2 nd tier risk assessment (Table 3). These are much higher than the ETR reported by Ansara-Ross et al. (2008), partly because of higher applied dosages (up to a factor of 3). In this study no risk was indicated for glyphosate (ETR: 0.019-0.21), which is comparable to the study in South Africa (Malherbe et al., 2013). In this study possible acute risks were also calculated for paraquat, dimethoate and carbendazim as the 1st tier ETRs ranged between 1.1 and 6.0, 1.2-4.7 and 6.4-13, respectively (Table 1). Paraquat showed possible acute risk based on a 1st tier assessment for both this study and that of Malherbe et al. (2013) (Table 1). This risk, however, disappears when a 2nd tier PNEC is used (Table 3). The calculated 1st and 2nd tier ETRs of dimethoate and carbendazim were much higher compared to the study of Malherbe et al. (2013), again a result of using much higher applied dosages (dimethoate up to a factor of 71, carbendazim up to a factor of 55). This is partly a result of the overdosing recorded by this study of a factor $2.3,12$ and 6.2 (Table 4) for pendimethalin, dimethoate and carbendazim respectively. Chlorpyrifos use (1st tier ETR = 3425 and 5479; 2nd tier ETR $=49$ and 79) in this study show definite acute risk to the aquatic environment which was also recorded by Wiratno et al. (2007) (1st tier ETR = 1900). Lambda cyhalothrin showed a definite risk (1st tier ETR $=274-4229$; 2 nd tier ETR = 193-2967; Tables 1 and 3 ) to the aquatic environment and cypermethrin showed an acute risk to the aquatic environment (1st and 2nd tier $\mathrm{ETR}=16,60$; Tables 1 and 3) and (ETR = 360; definite risk), while Wiratno et al. (2007) reported a lower value for lambdacyhalothrin (ETR $=3$ ) and higher one for cypermethrin $($ ETR $=360)$, but both predicting a (possible) risk. Van den Bosch et al. (2006) provided quite similar results for China and Vietnam with extremely high first ETR values $(>1000)$ for cypermethrin, chlorpyrifos, lambda cyhalothrin and dimethoate, high ones $(>100)$ for carbendazim and lower ones for mancozeb and, especially metalaxyl and metalaxyl-M. These results match the results of the 2nd tier risk assessment in our study although the highest ETR values are generally lower (Table 3 ). This points to the fact that the environmental side-effects of pesticide in countries with a weak pesticide registration system and enforcement needs more attention (Onwona Kwakye et al., 2019). This contamination of the aquatic ecosystem might not only harm the ecological integrity of the water, but also the ecosystem services for those who depend on such water sources for their livelihoods including reduced (drinking) water quality, reduced productivity (e.g., fish kills, effects on bees, cattle) and small ruminants that uses surface water as drinking water (Maltby et al., 2017).

The acute PNEC of 2,4-D is based on its toxicity to algae (EC50 $=24,200 \mu \mathrm{g} / \mathrm{L}$, while especially rooted macrophytes are much more sensitive. For instance, Belgers et al. (2007) found EC50 values for root length and number between 100 and $2000 \mu \mathrm{g} / \mathrm{L}$, which are much lower effect values compared to its algae toxicity. Van den Brink et al. (2006) calculated an SSD for submerged macrophytes for 2,4-D and found an acute HC5 value of $71 \mu \mathrm{g} / \mathrm{L}$ and a chronic one of $5.1 \mu \mathrm{g} / \mathrm{L}$. These values are still higher than the predicted acute and chronic exposure concentrations of 9.4 and
$0.32 \mu \mathrm{g} / \mathrm{L}$, respectively (Table SI 2). So even when submerged macrophyte toxicity data are included in the risk assessment, effects of the evaluated use patterns of 2,4-D are not expected.

PRIMET predicted no risk to the aquatic environment for the two neonicotinoid insecticides imidacloprid and thiamethoxam. It should be noted, however, that the standard test invertebrate Daphnia magna is relatively insensitive to imidacloprid with a geometric mean $96 \mathrm{~h}$ LC50 value of 34,000 $\mu \mathrm{g} / \mathrm{L}$ (Morrissey et al., 2015), while insect taxa like mayflies are at least four orders of magnitude more sensitive in temperate regions (96 h EC50 for Cloeon dipterum $=1.0 \mu \mathrm{g} / \mathrm{L}$ in The Netherlands (Roessink et al., 2013; Morrissey et al., 2015); and even seven orders of magnitude more sensitive in tropical regions ( $96 \mathrm{~h} \mathrm{EC}_{50}$ for Cloeon sp. $=0.0055 \mu \mathrm{g} / \mathrm{L}$ in Bangladesh; Sumon et al., 2018). Smit et al, (2015) report an acute and chronic HC5 of 0.72 and $0.025 \mu \mathrm{g} / \mathrm{L}$, respectively, based on toxicity data collected in temperate regions. These values could point to risks due to acute exposure as the acute and chronic calculated PECs are 0.72 and $0.034 \mu \mathrm{g} / \mathrm{L}$, respectively (Table SI 2). This risk could be higher as Ghana is also situated in the tropics. More research on the actual risks imidacloprid, and other neonicotinoid insecticides like thiamethoxam, poses to the aquatic ecosystem should be studied by testing local species. Thiamethoxam is also non-toxic to D. magna (96 h EC50 of $42,000 \mu \mathrm{g} / \mathrm{L}$; Morrissey et al., 2015) and highly toxic to aquatic insects like mayflies (Van den Brink et al., 2016).

Of the pesticides for which the 2nd tier risk assessment indicating a risk (ETR $>1$ ), no semi-field studies are available in the open literature for the herbicides pendimethalin, propanil and oxyfluorfen, the insecticide dimethoate and the fungicide carbofuran (Table 3; Van den Brink et al., 2006). Studies with the insecticide lambda cyhalothrin in experimental ecosystems have demonstrated that it is highly toxic to aquatic organisms (He et al., 2008). Reported effects of lambda cyhalothrin on arthropod invertebrates are likely to occur at concentrations at or above $0.01 \mu \mathrm{g} /$ L (Van Wijngaarden et al., 2004, 2005b), while our 2nd tier PNEC used was $0.003 \mu \mathrm{g} / \mathrm{L}$ (Table 3), making the second tier risks realistic. Lower-tier assessment of chlorpyrifos indicates risk for surface waters (Giesy et al., 1999; Giddings et al., 2014). Chlorpyrifos has also been studied extensively using microcosm and mesocosm (cosm) studies, single-species laboratory toxicity tests and used as a regulatory benchmarks across classes of insecticides (Brock et al., 2000, 2006; Maltby et al., 2005; Van Wijngaarden et al., 2005b). These cosm studies have also broadened the scope of conclusions about chlorpyrifos effects on aquatic communities to a wider range of locations and environmental conditions (Daam et al., 2008a, 2008b; López-Mancisidor et al., 2008a; 2008b; Van Wijngaarden et al., 2005a; Zafar et al., 2011), all supporting the conclusion that concentrations of $0.1 \mu \mathrm{g} / \mathrm{L}$ chlorpyrifos or less cause no ecologically significant effects on aquatic communities (Giddings et al., 2014; Brock et al., 2006) which could be used as basis for control measures in this study. This threshold value of $0.1 \mu \mathrm{g} / \mathrm{L}$ is close to the PNEC of $0.7 \mu \mathrm{g} / \mathrm{L}$ used in the 2 nd tier risk assessment (Table 3). Van Wijngaarden et al. (2005a, 2005b) reports for cypermethrin a NOEC and LOEC based on a cosm experiment evaluating multiple applications of $<0.07$ and $0.07 \mu \mathrm{g} / \mathrm{L}$, respectively. The 2nd tier PNEC of $0.003 \mu \mathrm{g} / \mathrm{L}$ is far below this value and is expected to be protective (Table 3). Several studies have indicated low 96 h LC50 value of mancozeb to fish, e.g. Oreochromis mossambicus ( $12 \mu \mathrm{g} / \mathrm{L})$, Punctius ticto $(13 \mu \mathrm{g} / \mathrm{L})$ and Clarius batracus adult $(14 \mu \mathrm{g} / \mathrm{L})$ and fingerlings (14 $\mu \mathrm{g} / \mathrm{L}$ ) (Saha et al., 2016; Srivastava and Singh, 2013; Sharma et al., 2016). Maltby et al. (2009) report a NOEC and LOEC derived from a cosm study using multiple applications of 10 and $32 \mu \mathrm{g} / \mathrm{L}$, respectively. This means that the 2 nd tier PNEC of $89 \mu \mathrm{g} / \mathrm{L}$ is on the high side when evaluating effects on fish and aquatic ecosystems as 
a whole, meaning that the 2nd tier risk assessment might even have underestimated the actual risks. For carbendazim, Maltby et al. (2009) reports a cosm based NOEC of $3 \mu \mathrm{g} / \mathrm{L}$ and a LOEC of $30 \mu \mathrm{g} / \mathrm{L}$ due to a single application, validating the 2nd tier PNEC of $8 \mu \mathrm{g} / \mathrm{L}$ used in this study. In a cosm experiment performed with maneb only a treament of $70 \mu \mathrm{g} / \mathrm{L}$ was evaluated, showing only clear effects on bivalves. This observation does not disqualify the PNEC of $48 \mu \mathrm{g} / \mathrm{L}$ used in this study. They also reported a cosm-based NOEC and LOEC of 12 and $24 \mu \mathrm{g} / \mathrm{L}$ for copper hydroxide, respectively, also supporting the 2nd tier PNEC of $5.4 \mu \mathrm{g} / \mathrm{L}$ used in this study (Table 3).

Both the 1st and the 2nd tier ecological threshold values are mainly based on toxicity values from temperate species. So it is uncertain whether temperate sensitivity data can be used for a risk assessment in warmer, tropical regions (Daam and Van den Brink, 2010). It was, however, indicated by studies conducted by Maltby et al. (2005) and Kwok et al. (2007), that no systematic difference existed in toxicity and sensitivity between tropical and temperate species for some of the selected pesticides (chlorpyrifos, fenitrothion and carbofuran), although differences do exist (e.g. imidacloprid; Sumon et al., 2018).

The tiered approach scheme can be employed by the Ghana Pesticide registration Authorities to support the registration of pesticides as has been demonstrated in this study to determine the risks associated the use of pesticide products in Ghana, again it has successfully been used in Europe for pesticide registration (EFSA, 2013b).

\subsection{Terrestrial risk assessment}

There is a considerable concern about decline in biodiversity that would influence the delivery of various ecosystem services by terrestrial invertebrates (Hole et al., 2005; Hooper et al., 2005). In agricultural intensification, the most affected ecosystem services at severe risk are biological pest control (Tscharntke et al., 2005; Geiger et al., 2010), crop pollination (Biesmeijer et al., 2006; MEA, 2005; Zhang et al., 2007) and soil fertility maintenance (Hole et al., 2005; Hansen et al., 2006; Goh, 2011; Pandey and Singh, 2012). There should therefore be specific protection goals aimed at protecting important ecosystem services such as food web support, pest control and biodiversity (Maltby et al., 2017). Biodiversity and ecosystem services might be protected along with agroecosystems, where farmers get subsidies, partly to produce ecological benefits (Kleijn et al., 2001).

Earthworms are important in influencing organic matter dynamics, soil structure and microbial community (Edwards and Bohlen, 1996; Fragoso et al., 1997; Sims and Gerard, 1999). They actively participate in soil aeration, water infiltration and mixture of soil horizons, and they represent an important source of food for many other organisms like birds or moles (Edwards and Bohlen, 1996; Lavelle et al., 2006) so there is the need to protect them from pesticide exposure. The study demonstrated that earthworms were also under acute risk for three pesticides (butachlor, dimethoate and carbendazim) and under chronic risks for nine pesticides, of which more than half are fungicides (Tables 1 and 2). The levels of risks were, however, much lower compared to the aquatic compartment (Tables 1 and 2). Strangely, the highest acute risk is calculated for the herbicide butachlor. According to the PPDB data base, butachlor is acutely toxic to earthworms with a 14d LC50 of $515 \mu \mathrm{g} / \mathrm{kg}$ (PPDB Pesticide Properties Database, 2020). Chen et al. (2014), however, report a 14d LC50 of $1198 \mathrm{mg} / \mathrm{kg}$ for the same species, so its value in the PPDB data base might be an error. In another study by Gobi and Gunasekaran (2009) butachlor reduced the biomass and cocoon production and caused damage to epithelial tissue of earthworm (Eisenia fetida) leading to the reduction of nutrient absorption area from food. Their study is important as they used concentrations $(0.26-2.6 \mathrm{mg} / \mathrm{kg})$ relevant for this study. The concentrations of dimethoate and carbendazim only slightly exceeded the acute PNEC (factor 2). Wiratno et al. (2007) provide similar results for Indonesia as found in our study where lambda cyhalothrin, chlorpyrifos and cypermethrin showed no acute risks to the terrestrial soil environment in both studies. The validity of the standard test species used for the risk assessment remains to be evaluated as the risk assessment of the soil compartment is still relatively understudied, especially in relation to exposure pathways and ecosystem level effects (Jänsch et al., 2006; Frampton et al., 2006), although exceptions exist, e.g. using terrestrial model ecosystems (Knacker et al., 2004).

The chronic risk assessment indicated a small risk for all pesticides towards the terrestrial environment (ETR $<10$; Table 2), except for carbendazim (ETR $=13$ ). Jänsch et al. (2006) reported a NOEC and LOEC of 2.16 and $3.24 \mathrm{~kg}$ a. i./ha while in our study application rates of 1.2 and $2.4 \mathrm{~kg}$ a. i./ha, both probably not leading to large adverse effects, although the actual values of the soil parameters like organic matter content and dry bulk density will be important.

As expected from the mode of action only for 1 out of 11 herbicides and 3 out of 9 fungicides a (possible) acute risk was indicated for bees, while for 8 out of 10 insecticides a (possible) acute risk was indicated (Table 1). Bees are most affected by lambda cyhalothrin, chlorpyrifos, emamectin benzoate, imidacloprid, thiametoxam, cypermethrin and dimethoate (ETR > 10). Some plants can produce guttation drops in the early hours of the morning (e.g. maize, strawberries), and systemic insecticides appear in such drops in elevated concentrations (Tapparo et al., 2011) that are capable of killing the bees (Zhu et al., 2017; Johnson et al., 2006). Pesticides may enter surface waters through run-off, leaching and spray-drift. Honey bees, bumblebees and wild bees drink from such puddles, irrigation ditches, ponds and streams, and if these waters are contaminated with pesticide residues may affect them (Samson-Robert et al., 2014; Schmaranzer, 2000). Since usage of these plant protection products cannot be stopped, chemical companies are obliged by law to state on the labels whether their products are dangerous to bees or not and must be enforced by the Ghana Registration Authority as well as communicating properly to applicators, farmers and beekeepers. More research is advocated for assessing the effects of chronic exposure of bees to pesticides taking into consideration recent approaches on how to improve the risk assessment of bees. (See e.g. EFSA European Food Safety Authority, 2013a; 2018). Also the validity of the used standard test species has been challenged as some studies that indicate that native tropical species (stingless bees) may be more sensitive than the standard test species used in temperate regions (Lourenço et al., 2012; Del Sarto et al., 2014).

Possible or definite risks for NTAs were identified for almost all pesticides for which a risk assessment could be performed (Table 1). This is not surprising as, some of the pesticides are designed to eradicate species which are closely related to NTAs and an in-field risk assessment was performed. Peeters et al. (2008), therefore, recommend to perform an off-field risk assessment as well, taking drift percentage and vegetation distribution factor into account. When the default values proposed by Peeters et al. (2008) are used the ETR in-field can be recalculated to an ETR $_{\text {off-field by }}$ dividing it by 0.0027 . In practice this means that all ETR in-field $_{\text {values }}$

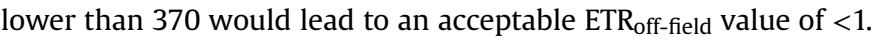

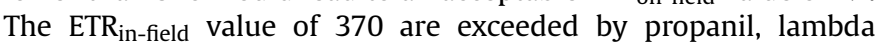
cyhalothrin, chlorpyrifos, imidacloprid and copper hydroxide. Jänsch et al. (2006) reviewed the (semi-)field experiments 
performed with NTAs and presented data for all these pesticides, except propanil and copper hydroxide. For lambda cyhalothrin only one dosage ( $1.5 \mathrm{~kg}$ a. i./ha) has been evaluated, which showed clear effects on some of the collembolan species (Jänsch et al., 2006). In our survey, we recorded use dosages of $0.14,0.15$ and $2.22 \mathrm{~kg}$ a. i./ ha, in-crop effects are certainly expected at the highest dosage. It is uncertain whether off-crop effects are to be expected as no fieldbased safe concentration could be derived. But since our 1st tier ETR $_{\text {in-field }}$ was above 370 they cannot be excluded. The same applies for chlorpyrifos. The lowest concentration of chlorpyrifos tested under (semi-) field circumstances was $0.48 \mathrm{~kg}$ a. i./ha, which already affected many species of collembolans (Jänsch et al., 2006). As the identified usage dosages of chlorpyrifos in our survey were 2.4 and $3.8 \mathrm{~kg}$ a. i./ha, in-crop effects are certainly to be expected. This is not the case for imidacloprid, which showed no field effects on collembolans at rates of $0.34 \mathrm{~kg}$ a. i./ha (Jänsch et al., 2006), while $0.12 \mathrm{~kg}$ a. i./ha was the use dosage recorded in our survey. Based on results from (semi-) field tests it is unclear whether infield effects on NTAs are expected from the $0.018 \mathrm{~kg}$ a. i./ha carbofuran which was recorded in our survey, as the lowest dosage tested in (semi-)field experiments was $0.75 \mathrm{mg}$ a. i./ha and already had clear effects on collembolans (Jänsch et al., 2006). Based on the 1 st tier assessment presented in this study for in-field as off-field are predicted (Table 1 ).

\subsection{Overdosing of pesticides}

Finally, in this study farmers generally used a higher dosage of pesticides than recommended, a factor of 1.3-13 times above the recommended label instructions. Mengistie et al. (2017) reported similar observations for small holder vegetable farmers in the central rift valley, Ethiopia, but indicated that assessing the exact level of overdosing proved difficult, because of unlabelled units (such as tins) and different combinations of pesticides were used. Similarly, Kariathi et al. (2016) reported farmers overdosing pesticide in tomato treatment in Tanzania and claimed that this was partly due to the presence of resistant pests and diseases. The use of pesticide in higher dosage than recommended may lead to pest resistance and high accumulation of residues as reported with increased risk of exposure in Tanzania (Ngowi et al., 2007). Farmers at these sites and in general should be encouraged by the scheme managers, extension service providers and the Ghana registration authorities to limit the application of pesticides products to recommended rates to prevent acute risks to the aquatic environment.

The implementation of alternative cropping systems that are less dependent on pesticides, the development of new pesticides with novel modes of action and improved safety profiles, and the improvement of the already used pesticide formulations towards safer formulations (e.g. microcapsule suspensions) have been suggested could reduce the adverse effects of farming and particularly the toxic effects of pesticides. In addition, the use of appropriate and well-maintained spraying equipment along with taking all precautions that are required in all stages of handling and applying pesticides to possibly minimize pesticides potential adverse effects on the environment (Damalas and Eleftherohorinos, 2011).

We recommend more toxicity studies are conducted on datapoor pesticides to generate the necessary information to feed an appropriate environmental risk assessment and the use of the PRIMET model by the Ghana Pesticide Authority and other developing countries as a guide in making pesticide registration decisions, although some contamination routes need to be added (e.g. run-off to the aquatic compartment) and some risk assessments needs to be updates (e.g. bees).

\section{Declaration of competing interest}

The authors declare that they have no known competing financial interests or personal relationships that could have appeared to influence the work reported in this paper.

\section{Acknowledgements}

The authors would like to thank the Ghana Education Trust Fund (GETFund) for the funding of this project. We would also like to thank Nana Domtie Onwona-Kwakye for all the help with this project.

\section{Appendix A. Supplementary data}

Supplementary data to this article can be found online at https://doi.org/10.1016/j.chemosphere.2020.126845.

\section{References}

Abban, T., Johnson, F.A., Dash, J., Padmadas, S.S., 2018. Spatiotemporal variations in rainfall and temperature in Ghana over the twentieth century, $1900-2014$ Earth Space Sci 5, 120-132.

Acquaah, S.O., 1997. Lindane and endosulfan residues in water and fish in the Ashanti region of Ghana. Proceed. Symp. on Environ. Behav. Crop Protect. Chemicals by the IAEA/FAO, 1-5 July 1997, Vienna, Austria.

Aktar, M.W., Sengupta, D., Chowdhury, A., 2009. Impact of pesticides use in agriculture: their benefits and hazards. Interdiscipl. Toxicol. 2, 1-12.

Aldenberg, T., Jaworska, J.S., 2000. Uncertainty of the hazardous concentration and fraction affected for normal species sensitivity distributions. Ecotoxicol. Environ. Saf. 46, 1-18.

Ansara-Ross, T.M., Wepener, V., Van den Brink, P.J., Ross, M.J., 2008. Probabilistic risk assessment of the environmental impacts of pesticides in the Crocodile (west) Marico catchment. North-West Province. Water SA 34, 637-644.

Belgers, J.D.M., Van Lieverloo, R.J., Van der Pas, L.J.T., Van den Brink, P.J., 2007. Effects of the herbicide 2,4-D on the growth of nine aquatic macrophyte species. Aquat. Bot. 86, 260-268.

Biesmeijer, J.C., Roberts, S.P.M., Reemer, M., Ohlemuller, R., Edwards, M., et al., 2006. Parallel declines in pollinators and insect-pollinated plants in Britain and The Netherlands. Science 313, 351-354.

Brock, T.C.M., Van Wijngaarden, R.P.A., 2012. Acute toxicity tests with Daphnia magna, Americamysis bahia, Chironomus riparius and Gammarus pulex and implications of new EU requirements for the aquatic effect assessment of insecticides. Environ. Sci. Pollut. Res. 19, 3610-3618.

Brock, T.C.M., Bhatta, R., van Wijngaarden, R.P.A., Rico, A., 2016. Is the chronic tier-1 effect assessment approach for insecticides protective for aquatic ecosystems? Integr. Environ. Assess. 12, 747-758.

Brock, T.C.M., Van Wijngaarden, R.P.A., Van Geest, G.J., 2000. Ecological Risks of Pesticides in Freshwater Ecosystems. Part 2: Insecticides. Alterra report 089, Wageningen, The Netherlands, p. 143.

Brock, T.C.M., Arts, G.H.P., Maltby, L., Van den Brink, P.J., 2006. Aquatic risks of pesticides, ecological protection goals and common aims in EU legislation. Integr. Environ. Assess. 2, e20. -e46.

Chen, C., Wang, Y., Zhao, X., Wang, Q., Qian, Y., 2014. Comparative and combined acute toxicity of butachlor, imidacloprid and chlorpyrifos on earthworm, Eisenia fetida. Chemosphere 100, 111-115.

Daam, M.A., Van den Brink, P.J., 2010. Implications of differences between temperate and tropical freshwater ecosystems for the ecological risk assessment of pesticides. Ecotoxicology 19, 24-37.

Daam, M.A., Crum, S.J., Van den Brink, P.J., Nogueira, A.J., 2008a. Fate and effects of the insecticide chlorpyrifos in outdoor plankton-dominated microcosms in Thailand. Environ. Toxicol. Chem. 27, 2530-2538.

Daam, M.A., Van den Brink, P.J., Nogueira, A.J., 2008b. Impact of single and repeated applications of the insecticide chlorpyrifos on tropical freshwater plankton communities. Ecotoxicology 17, 756-771.

Damalas, C.A., Eleftherohorinos, I.G., 2011. Pesticide exposure, safety issues, and risk assessment indicators. Int. J. Environ. Res. Publ. Health 8, 1402-1419.

De Zwart, D., 2002. Observed regularities in species sensitivity distributions for aquatic species. In: Posthuma, L., Suter, G., Traas, T. (Eds.), Species Sensitivity Distributions in Ecotoxicology. Lewis, USA, Boca Raton, FL, pp. 133-154.

Del Sarto, M.C.L., Oliveira, E.E., Guedes, R.N.C., Campos, L.A.O., 2014. Differential insecticide susceptibility of the Neotropical stingless bee Melipona quadrifasciata and the honey bee Apis mellifera. Apidologie 45, 626-636.

Dickson, K.B., Benneh, G., 1998. A New Geography of Ghana. England. Longman, Harlow, UK, p. 173.

Edwards, C.A., Bohlen, P.J., 1996. Biology and Ecology of Earthworms, third ed. Chapman \& Hall, London, UK, p. 442.

EU (European Union), 1997. Council Directive 97/57/EC of September 21, 1997 Establishing annex VI to Directive 91/414/EEC concerning the placing of plant 
protection products on the market. Off. J. L265, 87-109.

EFSA (European Food Safety Authority), 2013a. EFSA Guidance Document on the risk assessment of plant protection products on bees (Apis mellifera, Bombus spp. and solitary bees). EFSA Journal 11, 3295.

EFSA (European Food Safety Authority), 2013b. Guidance on tiered risk assessment for plant protection products for aquatic organisms in the edge-of-field surface waters. EFSA Journal 11, 3290.

EFSA (European Food Safety Authority), 2018. Conclusions on the peer review of the pesticide risk assessment for bees for the active substance thiamethoxan considering the uses as seed treatments and granules. EFSA Journal 16, 5179.

Fragoso, C., Brown, G.G., Patron, J.C., Blanchart, E., Lavelle, P., Pashanasi, B. Senapati, B., Kumar, T., 1997. Agricultural intensification, soil biodiversity and (he tropics: the role of earthworms. Appl. Soil Ecol. $6,17-35$

Frampton, K.G., Jänsch, S., Scott-Fordsmand, J.J., Römbke, J., Van den Brink, P.J., 2006. Effects of pesticides on soil invertebrates in laboratory studies: A review and analysis using species sensitivity distributions. Env. Toxicol. Chem. 25, 2480-2489. https://doi.org/10.1897/05-438R.1.

Geiger, F., Bengtsson, J., Berendse, F., Weisser, W.W., Emmerson, M., et al., 2010 Persistent negative effects of pesticides on biodiversity and biological control potential on European farmland. Basic Appl. Ecol. 11, 97-105.

Ghana Epa, 2015. Environmental protection agency, Ghana. Annual Report, Accra, Ghana, p. 83.

GSS (Ghana Statistical Service), 2014. Ghana Living Standards Survey Round 6 Accra, Ghana, p. 244

GSS (Ghana Statistical Service), 2015. Revised 2014 Annual Gross Domestic Product. Accra, Ghana, p. 14

Giddings, J.M., Williams, W.M., Solomon, K.R., Giesy, J.P., 2014. Risks to aquatic organisms from use of chlorpyrifos in the United States. In: Giesy, J., Solomon, K. (Eds.), Ecological Risk Assessment for Chlorpyrifos in Terrestrial and Aquatic Systems in the United States. Rev. Environ. Contam. T., vol. 231, pp. 119-162.

Giesy, J.P., Solomon, K.R., Coates, J.R., Dixon, K.R., Giddings, J.M., Kenaga, E.E., 1999 Chlorpyrifos: ecological risk assessment in North American aquatic environments. Rev. Environ. Contam. Toxicol. 160, 1-129.

Gobi, M., Gunasekaran, P., 2009. Effect of butachlor herbicide on earthworm Eisenic fetida - its histological perspicuity. Appl. Environ. Soil Sci. 2010, 850758.

Goh, K.M., 2011. Greater mitigation of climate change by organic than conventional agriculture: a review. Biol. Agric. Hortic. 27, 205-229.

Grizzetti, B., Lanzanova, D., Liquete, C., Reynaud, A., Cardoso, A.C., 2016. Assessing water ecosystem services for water resource management. Environ. Sci. Pol. 61, $194-203$.

Hansen, L., Noe, E., Hojring, K., 2006. Nature and nature values in organic agriculture. An analysis of contested concepts and value among different actors in organic farming. J. Agric. Environ. Ethics 19, 147-168.

He, L.M., Troiano, J., Wang, A., Goh, K., 2008. Environmental chemistry, ecotoxicity, and fate of lambda-cyhalothrin. Rev. Environ. Contam. Toxicol. 195, 71-91.

Hole, D.G., Perkins, A.J., Wilson, J.D., Alexander, I.H., Grice, P.V., Evans, A.D., 2005. Does organic farming benefit biodiversity. Biol. Conserv. 122, 113-130.

Hooper, D.U., Chapin III, F.S., Ewel, J.J., Hector, A. Inchausti, Lavorel, A.S., Lawton, J.H., Lodge, D.M., Loreau, M., Naeem, S., Schmid, B., Setälä, H., Symstad, A.J., Vandermeer, J., Wardle, D.A., 2005. Effects of biodiversity on ecosystem functioning: a consensus of current knowledge. Ecol. Monogr. 75, 3-35.

Jänsch, S., Frampton, G.K., Römbke, J., Van den Brink, P.J., Scott-Fordsmand, J.J., 2006 Effects of pesticides on soil invertebrates in model ecosystem and field studies: a review and comparison with laboratory toxicity data. Environ. Toxicol. Chem. $25,2490-2501$

Johnson, R.M., Wen, Z., Schuler, M.A., Berenbaum, M.R., 2006. Mediation of pyrethroid insecticide toxicity to honey bees (hymenoptera: apidae) by cytochrome p450 monooxygenases. J. Econ. Entomol. 99, 1046-1050.

Kariathi, V., Kassim, N., Kimanya, M., 2016. Pesticide exposure from fresh tomatoes and its relationship with pesticide application practices in Meru district. Cogent Food Agric 2, 1196808

Kleijn, D., Berendse, F., Smit, R., Gilissen, N., 2001. Agri environment schemes do not effectively protect biodiversity in Dutch agricultural landscapes. Nature 413 $723-725$.

Knacker, T., Van Gestel, C.A.M., Jones, S.E., Soares, A.M.V.M., Schallnaß, H.-J, Förster, B., Edwards, C.A., 2004. Ring-testing and field-validation of a terrestrial model ecosystem (TME) - an instrument for testing potentially harmful substances: conceptual approach and study design. Ecotoxicology 13, 5-23.

Kwok, K.W.H., Leung, K.M.Y., Lui, G.S.G., Chu, V.K.H., Lam, P.K.S., Morritt II, D., Maltby, L., Brock, T.C.M., Van den Brink, P.J., Warne, M.S.J., Crane, M., 2007. Comparison of tropical and temperate freshwater animal species' acute sensitivities to chemicals: implications for deriving safe extrapolation factors. Integr. Environ. Assess. 3, 49-67.

Lavelle, P., Decaëns, T., Aubert, M., Barot, S., Blouin, M., Bureau, F., Margerie, P., Mora, P., Rossi, J.P., 2006. Soil invertebrates and ecosystem services. Eur. J. Soil Biol. 42. S3-S15.

López-Mancisidor, P., Carbonell, G., Fernandez, C., Tarazona, J.V., 2008a. Ecological impact of repeated applications of chlorpyrifos on zooplankton community in mesocosms under Mediterranean conditions. Ecotoxicology 17, 811-825.

López-Mancisidor, P., Carbonell, G., Marina, A., Fernandez, C., Tarazona, J.V., 2008b. Zooplankton community responses to chlorpyrifos in mesocosms under Mediterranean conditions. Ecotoxicol. Environ. Saf. 71, 16-25.

Lourenço, C.T., Carvalho, S.M., Malaspina, O., Nocelli, R.C.F., 2012. Oral toxicity of fipronil insecticide against the stingless bee melipona scutellaris (latreille
1811). Bull. Environ. Contam. Toxicol. 89, 921-924

Malherbe, W. van Vuren, J.H.J. Wepener, V., 2013. Preliminary risk assessment of common-use pesticides using PRIMET and PERPEST pesticide risk models in a semi-arid subtropical region. WaterSA 39, 599-610.

Maltby, L., Blake, N., Brock, T.C.M., Van den Brink, P.J., 2005. Insecticide species sensitivity distributions: importance of test species selection and relevance to aquatic ecosystems. Environ. Toxicol. Chem. 24, 379-388.

Maltby, L., Brock, T.C.M., van den Brink, P.J., 2009. Fungicide risk assessment for aquatic ecosystems: importance of interspecific variation, toxic mode of action, and exposure regime. Environ. Environ. Sci. Technol. 43, 7556-7563.

Maltby, L., Van den Brink, P.J., Faber, J.H., Marshall, S., 2017. Advantages and challenges associated with implementing an ecosystem services approach to ecological risk assessment for chemicals. Sci. Total Environ. 621, 1342-1351.

MEA (Millennium Ecosystem Assessment), 2005. Ecosystems and Human WellBeing: Synthesis. Island Press, Washington, DC., USA, p. 160.

Mengistie, B.T., Mol, A.P.J., Oosterveer, P., 2017. Pesticide use practices among smallholder vegetable farmers in Ethiopian Central Rift Valley. Environ. Dev. Sustain. 19, 301-324.

MOFA Ministry of Food and Agriculture, 2003. Agriculture in Ghana: Facts and Figures. Statistics, Research and Information Directorate, Accra, Ghana.

MOFA Ministry of Food and Agriculture, 2011. Agriculture in Ghana: Facts and Figures. Statistics, Research and Information Directorate, Accra, Ghana.

Morrissey, C.A., Mineau, P., Devries, J.H., Sanchez-Bayo, F., Liess, M., Cavallaro, M.C., Liber, K., 2015. Neonicotinoid contamination of global surface waters and associated risk to aquatic invertebrates: a review. Environ. Int. 74, 291-303.

Ngowi, A., Mbise, T., Ijani, A., London, L., Ajayi, O., 2007. Smallholder vegetable farmers in Northern Tanzania: pesticides use practices, perceptions, cost and health effects. Crop Protect. 26, 1617-1624.

NPASP (Northern Presbyterian Agricultural Services and Partners), 2012. Ghana's Pesticide Crisis: the Need for Further Government Action. Accra, Ghana, p. 50. Accessed. http://curtisresearch.org/wp-content/uploads/NPAS.PesticidesReport.-Final.-17-April-2012.pdf. (Accessed February 2020).

Ntow, W.J., 2001. Organochlorine pesticides in water, sediment, crops and human fluids in a farming community in Ghana. Arch. Environ. Contam. Toxicol. 40, $557-563$.

Ntow, J.W., 2005. Pesticide residues in Volta Lake, Ghana. Lakes Reserv 10, 243-248.

Onwona Kwakye, M., Mengistie, B., Ofosu-Anim, J., Tetteh Nuer, A.K., Van den Brink, P.J., 2019. Pesticide registration, distribution and use practices in Ghana. Environ. Dev. Sustain. 21, 2667-2691.

Pandey, J., Singh, A., 2012. Opportunities and constraints in organic farming: an Indian perspective. J. Sci. Res. 56, 47-72.

Peeters, F.M., Van den Brink, P.J., Vlaming, J., Groenwold, J.G., Beltman, W.H.J., Boesten, J.J.T.I., 2008. PRIMET Version 2.0 Manual and Technical Description. A Decision Support System for Assessing Pesticides Risk in the Tropics to Man, Environment and Trade. In: Alterra-report 1648, p. 77. Wageningen, The Netherlands.

PPDB Pesticide Properties Database, 2020. Pesticide Properties Database (PPDB). University of Hertfordshire, UK. Available at: https://sitem.herts.ac.uk/aeru/ ppdb/en/index.htm. (Accessed February 2020)

Rico, A., Brock, T.C.M., Daam, M.A., 2019. Is the effect assessment approach for fungicides as laid down in the European food safety authority aquatic guidance document sufficiently protective for freshwater ecosystems? Environ. Toxicol. Chem. 38, 2279-2293.

Roessink, I., Merga, L.B., Zweers, H.J., Van den Brink, P.J., 2013. The neonicotinoid imidacloprid shows high chronic toxicity to mayfly nymphs. Environ. Toxicol. Chem. 32, 1096-1100.

Saha, N.C., Giri, S.K., Chatterjee, N., Biswas, S.J., Bej, S., 2016. Acute toxic effects of Mancozeb to fish Oreochromis mossambicus (W. K. H. Peters, 1852) and their behavior. Int. J. Adv. Res. Biol. Sci. 3, 40-44.

Sally, H.A., Abernethy, C.L., 2002. Private Irrigation in Sub-saharan Africa: Regional Seminar on Private Sector Participation and Irrigation Expansion in Subsaharan Africa, Accra, Ghana, 22-26 October 2001. International Water Management Institute (IWMI), Rome, Italy, p. 307. FAO; Wageningen, Netherlands: Technical Centre for Agricultural and Rural Cooperation ACP-EU (CTA) Colombo, Sri Lanka.

Samson-Robert, O., Labrie, G., Chagnon, M., Fournier, V., 2014. Neonicotinoidcontaminated puddles of water represent a risk of intoxication for honey bees. PloS One 9, e108443.

Schmaranzer, S., 2000. Thermoregulation of water collecting honey bees (Apis mellifera). J. Insect Physiol. 46, 1187-1194.

Sharma, M.R., Mushtaq, R., Allayie, S.A., Vardhan, H., 2016. Assessment of lethal toxicity of mancozeb and its consequences on the behavior of fresh water fish, Puntius ticto. J. Int. Acad. Res. Multidiscip.J. Biol. Earth Sci. 4, 132-138.

Sims, R.W., Gerard, B.M., 1999. Earthworms. FSC Publications, London, UK.

Smit, C.E., Posthuma-Doodeman, C.J.A.M., van Vlaardingen, P.L.A., de Jong, F.M.W., 2015. Ecotoxicity of imidacloprid to aquatic organisms: derivation of water quality standards for peak and long-term exposure. Hum. Ecol. Risk Assess. 21, $1608-1630$

Snelder, D.J., Masipiquena, M.D., de Snoo, G.R., 2008. Risk assessment of pesticide usage by smallholder farmers in the Cagayan Valley (Philippines). Crop Protect. 27, 747-762.

Srivastava, P., Singh, A., 2013. In vivo study of effects of dithiocarbamates fungicide (Mancozeb) and its metabolite ethylenethiourea (ETU) on freshwater fish Clarius batrachus. Journal of Biology and Earth Sciences 3, 228-235.

Sumon, K.A., Ritika, A.K., Peeters, E.T.H.M., Rashid, H., Bosma, R.H., Rahman, M.S., 
Fatema, M.K., Van den Brink, P.J., 2018. Effects of imidacloprid on the ecology of sub-tropical freshwater microcosms. Environ. Pollut. 236, 432-441.

Tapparo, A., Giorio, C., Marzaro, M., Marton, D., Solda, L., Girolami, V., 2011. Rapid analysis of neonicotinoid insecticides in guttation drops of corn seedlings obtained from coated seeds. J. Environ. Monit. 13, 1564-1568.

Tscharntke, T., Klein, A.M., Kruess, A., Steffan-Dewenter, I., Thies, C., 2005. Landscape perspectives on agricultural intensification and biodiversity-ecosystem service management. Ecol. Lett. 8, 857-874.

Tomlin, C.D.S., 2000. The Pesticide Manual, twelfth ed. British Crop Protection Council, Farnham, UK, p. 769.

USEPA United States Environmental Protection Agency, 2020a. ECOTOX User Guide: ECOTOXicology Knowledgebase System. U.S. EPA, Washington DC, USA Accessed. www.epa.gov/ecotox. (Accessed February 2020).

USEPA United States Environmental Protection Agency, 2020b. CADDIS Volume 4 SSD Generator V1. U.S. EPA, Washington DC, USA. Accessed. https://www.epa. gov/caddis-vol4/caddis-volume-4-data-analysis-download-software. (Accessed February 2020).

Van den Bosch, H., Chaowen, L., Pham Van Hoi, Ter Horst, M.M.S., Van den Brink, P.J., Yunliang, P., Groenwold, J.G., Yibing, C., Van Dung, N., Van Wijk, M.S. Vlaming, J., 2006. Environmental Risks of Pesticide Use in Intensive Vegetable Farming Systems in Periurban Hanoi (Dong Anh) and Chengdu (Pengzhou). Alterra Report 1285, p. 166. Wageningen, The Netherlands.

Van den Brink, P.J., Ter Horst, M.M.S., Beltman, W.H.J., Vlaming, J., Van den Bosch, H. 2005. PRIMET Version 1.0, Manual and Technical Description. A Decision Support System for Assessing Pesticide Risks in the Tropics to Man, Environment and Trade, vol. 1185. Alterra report, Wageningen, The Netherlands, p. 60.

Van den Brink, P.J., Blake, N., Brock, T.C.M., Maltby, L., 2006. Predictive value of species sensitivity distributions for effects of herbicides in freshwater ecosystems. Hum. Ecol. Risk Assess. 12, 645-674.

Van den Brink, P.J., Van Smeden, J.M., Bekele, R.S., Dierick, W. De Gelder, D.M. Noteboom, M., Roessink, I., 2016. Acute and chronic toxicity of neonicotinoids to nymphs of a mayfly species and some notes on seasonal differences. Environ. Toxicol. Chem. 35, 128-133.

Van Wijngaarden, R.P.A., Arts, G.H.P., 2018. Is the Tier-1 Effect assessment for herbicides protective for aquatic algae and vascular plant communities? Environ. Toxicol. Chem. 37, 175-183.

Van Wijngaarden, R.P.A., Cuppen, J.G.M., Arts, G.H.P., Crum, S.J.H., van den Hoorn, M.W., Van den Brink, P.J., Brock, T.C.M., 2004. Aquatic risk assessment of a realistic exposure to pesticides used in bulb crops: a microcosm study. Environ. Toxicol. Chem. 23, 1479-1498.

Van Wijngaarden, R.P., Brock, T.C., Douglas, M.T., 2005a. Effects of chlorpyrifos in freshwater model ecosystems: the influence of experimental conditions on ecotoxicological thresholds. Pest Manag. Sci. 61, 923-935.

Van Wijngaarden, R.P.A., Brock, T.C.M., Van den Brink, P.J., 2005b. Threshold levels for effects of insecticides in freshwater ecosystems: a review. Ecotoxicology 14, $355-380$.

Van Wijngaarden, R.P.A., Maltby, L., Brock, T.C.M., 2015. Acute tier-1 and tier-2 effect assessment in the new EFSA Aquatic Guidance Document. Pest Manag. Sci. 71, 1059-1067.

Vijver, M.G., Hunting, E.R., Nederstigt, T.A.P., Tamis, W.L.M., Van den Brink, P.J., van Bodegom, P.M., 2017. Postregistration monitoring of pesticides is urgently required to protect ecosystems. Environ. Toxicol. Chem. 36, 860-865.

WAAPP West Africa Agricultural Productivity Programme, 2014. Annual Report Accra, Ghana, p. 129. Accessed. https://waapp.org.gh/waappmedia/reports. (Accessed February 2020).

Wiratno, W., Taniwiryono, D., Van den Brink, P.J., Rietjens, I., Murk, A., 2007. A case study on Bangka Island, Indonesia on the habits and consequences of pesticide use in pepper plantations. Environ. Toxicol. 22, 405-414.

Zafar, M.I., Van Wijngaarden, R.P., Roessink, I., Van den Brink, P.J., 2011. Effects of time-variable exposure regimes of the insecticide chlorpyrifos on freshwater invertebrate communities in microcosms. Environ. Toxicol. Chem. 30, 1383-1394.

Zhang, W., Ricketts, T.H., Kremen, C., Carney, K., Swinton, S.M., 2007. Ecosystem services and dis-services to agriculture. Ecol. Econ. 64, 253-260.

Zhu, Y.C., Yao, J., Adamczyk, J., Luttrell, R., 2017. Synergistic toxicity and physiological impact of imidacloprid alone and binary mixtures with seven representative pesticides on honey bee (Apis mellifera). PloS One 12, e0176837. 